\title{
THE CONDITION OF CELLULAR IMMUNITY IN PATIENTS WITH OSTEOARTHROSIS BEFORE AND AFTER ENDOPROSTHESIS IMPLANTATION
}

\author{
S.V. Belova, E.V. Gladkova, V.Yu. Ulyanov, R.A. Zubavlenko, V.V. Blinnikova \\ Scientific Research Institute of Traumatology, Orthopedics and Neurosurgery \\ of Saratov State Medical University n.a. V.I. Razumovsky, Saratov, Russia
}

\section{СОСТОЯНИЕ КЛЕТОЧНОГО ЗВЕНА ИММУНИТЕТА ПАЦИЕНТОВ С ОСТЕОАРТРОЗОМ В УСЛОВИЯХ ЭНДОПРОТЕЗИРОВАНИЯ}

\author{
С.В. Белова, Е.В. Гладкова, В.Ю. Ульянов, Р.А. Зубавленко, В.В. Блинникова
}

Научно-исследовательский институт травматологии, ортопедии и нейрохирургии ФГБОУ ВО «Саратовский государственный медицинский университет им. В.И. Разумовского» Минздрава России, Саратов

Impairments of immune system are an important mechanism of the degenerative dystrophic processes in the arthral tissues onset and development.The objective of this research was to study the cellular immunity condition in patients with osteoarthrosis before and after endoprosthesis implantation. The research methods included immunophenotyping of lymphocytes in the peripheral blood. The immunologic impairments before the surgery referred to change in T-cell immunity reflecting in the imbalance of immunoregulatory subpopulations (decrease of T-suppressor level and increase of T-helper content). At that the number of NK-cells rose which didn't exclude a possible connection with the cartilage tissue degradation impurities on the background of B-cell number decrease. During the post-surgery period the decrease in T-helper and T-suppressor numbers was detected which may be related to their migration to implantation area due to the decrease of their number in the systemic circulation, at that no significant changes in T-lymphocytes were observed. By contrast, there was a decrease of NK-cell number at higher level of B-cell number showing an adequate response of the bodies for surgery aggression. The results of immunological research are worth being taken into account when preparing patients for endoprosthesis implantation surgery for the purpose of prescribing the immune-correcting drugs for pre-existing impairments of cellular immunity as well as in the post-surgery period to relieve the effects of surgical interference aggravating the impairments in this population of patients.

Keywords: endoprosthesis; cellular immunity.

Важным механизмом возникновения и развития дегенеративно-дистрофических процессов в суставных тканях являются нарушения в иммунной системе. Цель исследования заключалась в изучении состояния клеточного звена иммунитета у пациентов с остеоартрозом в условиях эндопротезирования коленных суставов. Методы исследования включали иммунофенотипирование лимфоцитов в периферической крови. Имеющиеся иммунологические нарушения в дооперационном периоде касались изменения Т-клеточного звена иммунитета, что выражалось дисбалансом иммунорегуляторных субпопуляций (снижение уровня Т-супрессоров и повышение содержания Т-хелперов). При этом имелось увеличение количества NK-клеток, не исключающее возможной связи с продуктами деградации хрящевой ткани, на фоне снижения числа В-клеток. В послеоперационном периоде было выявлено снижение числа Т-хелперов и Т-супрессоров, возможно связанное с их миграцией в зону имплантации, за счет снижения их количества в системном кровотоке, при этом существенных изменений со стороны Т-лимфоцитов не наблюдалось. На этом фоне имелось снижение числа NK-клеток при повышенном уровне В-клеток, что показывает адекватную ответную реакцию организма на хирургическую агрессию. Результаты иммунологических исследований целесообразно учитывать в предоперационной подготовке пациентов к эндопротезированию в целях назначения иммунокорректирующих препаратов существующих нарушений в системе клеточного иммунитета, а также в послеоперационном периоде для ликвидации последствий хирургического вмешательства, усугубляющего имеющиеся нарушения у данного контингента.

Ключевые слова: эндопротезирование; клеточное звено иммунитета.

Introduction. Impairments of immune system are an important mechanism of the degenerative dystrophic processes in the arthral tissues onset and development $[1,2]$.

The objective is researching of the cellular immunity condition in patients with osteoarthrosis before and after endoprosthesis implantation.

Material and methods. Knee endoprosthesis implantation was performed on 23 female patients with III-IV stages of post-traumatic osteoarthrosis. The control group consisted of 11 women of the similar age.

Lymphocytes immunophenotyping was performed using the laser flow cytofluorometry method on BD FACSCantoII cytometer (BD, CШA). The results are presented in the form of a median with the lowest and the topmost quartiles being indicated. 
Cellular Immunity Indices

\begin{tabular}{|c|c|c|c|c|c|c|}
\hline \multirow{3}{*}{ Indices } & \multirow{2}{*}{\multicolumn{2}{|c|}{$\begin{array}{l}\text { Control Group } \\
(n=11)\end{array}$}} & \multicolumn{4}{|c|}{ Research Period } \\
\hline & & & \multicolumn{2}{|c|}{$\begin{array}{l}\text { Before Endoprosthesis Implantation } \\
\qquad(n=23)\end{array}$} & \multicolumn{2}{|c|}{$\begin{array}{l}\text { 3-6 Days After Endoprosthesis } \\
\text { Implantation }(n=22)\end{array}$} \\
\hline & Absolute Number & $\%$ & Absolute Number & $\%$ & Absolute Number & $\%$ \\
\hline T-lymphocytes & $\begin{array}{c}1791.1 \\
(1711.4 ; 1811.5)\end{array}$ & $\begin{array}{c}72.2 \\
(71.5 ; 75.1)\end{array}$ & $\begin{array}{c}1275.0 \\
(1119.1 ; 1362.1) \\
p<0.001\end{array}$ & $\begin{array}{c}71.3 \\
(70.5 ; 71.9) \\
p<0.05\end{array}$ & $\begin{array}{c}910.4 \\
(907.0 ; 912.8) \\
p_{1}<0.001\end{array}$ & $\begin{array}{c}66.2 \\
(63.1 ; 69.9) \\
p_{1}<0.001\end{array}$ \\
\hline T-suppressors & $\begin{array}{c}656.1 \\
(631.8 ; 664.6)\end{array}$ & $\begin{array}{c}29.6 \\
(28.7 ; 32.7)\end{array}$ & $\begin{array}{c}378.50 \\
(366.90 ; 392.40) \\
p<0.001\end{array}$ & $\begin{array}{c}22.90 \\
(21.10 ; 24.00) \\
p<0.001\end{array}$ & $\begin{array}{c}272.4 \\
(268.1 ; 278.1) \\
p_{1}<0.001\end{array}$ & $\begin{array}{c}23.4 \\
(21.2 ; 26.0)\end{array}$ \\
\hline T-helpers & $\begin{array}{c}862.5 \\
(845.9 ; 866.1)\end{array}$ & $\begin{array}{c}40.8 \\
(39.0 ; 41.5)\end{array}$ & $\begin{array}{c}981.0 \\
(973.2 ; 984.5) \\
p<0.001\end{array}$ & $\begin{array}{c}45.2 \\
(41.3 ; 47.1) \\
p<0.05\end{array}$ & $\begin{array}{c}615.1 \\
(603.7 ; 634.1) \\
p_{1}<0.001\end{array}$ & $\begin{array}{c}48.7 \\
(47.0 ; 50.3) \\
p_{1}<0.05\end{array}$ \\
\hline NK-cells & $\begin{array}{c}228.3 \\
(215.7 ; 232.6)\end{array}$ & $\begin{array}{c}11.0 \\
(10.2 ; 11.8)\end{array}$ & $\begin{array}{c}267.8 \\
(258.3 ; 278.5) \\
p<0.001\end{array}$ & $\begin{array}{c}16.6 \\
(16.1 ; 17.7) \\
p<0.001\end{array}$ & $\begin{array}{c}160.0 \\
(150.7 ; 173.1) \\
p_{1}<0.001\end{array}$ & $\begin{array}{c}12.6 \\
(11.2 ; 13.3) \\
p_{1}<0.001\end{array}$ \\
\hline B- lymphocytes & $\begin{array}{c}322.7 \\
(312.0 ; 325.6)\end{array}$ & $\begin{array}{c}15.2 \\
(13.8 ; 16.0)\end{array}$ & $\begin{array}{c}224.9 \\
(218.9 ; 229.5) \\
p<0.001\end{array}$ & $\begin{array}{c}12.7 \\
(12.2 ; 14.1) \\
p<0.01\end{array}$ & $\begin{array}{c}243.7 \\
(240.1 ; 247.4) \\
p_{1}<0.001\end{array}$ & $\begin{array}{c}17.9 \\
(17.2 ; 18.9) \\
p_{1}<0.001\end{array}$ \\
\hline
\end{tabular}

Note. $p$ - veracity in relation to the control group data; $p_{1}$ - veracity in relation to indices before endoprosthesis implantation.

Results and discussion. Compared to indices in the control group, the decrease in T-lymphocyte number was observed in patients before the surgery mainly owing to T-suppressors on the background of the increase in T-helper number and NK-cell number with the moderate decrease in B-cell number (Table 1).

During the post-surgery period, the decrease in $\mathrm{T}$-helper and $\mathrm{T}$-suppressor numbers in patients was established which may be related to their migration to implantation area due to the decrease of their number in the systemic circulation, at that no sig- nificant changes in T-lymphocytes were observed. At the same time there was a decrease of NK-cell number at higher level of B-cell number (Table 1).

Conclusion. The results of this research are worth being taken into account when preparing patients for endoprosthesis implantation surgery for the purpose of prescribing the immune-correcting drugs for pre-existing impairments of cellular immunity as well as in the post- surgery period to relieve the effects of surgical interference aggravating the impairments in this population of patients.

\section{References}

1. Dmitrieva LA, Korshunova EY, Lebedev VF. Immunological Manifestations in Patients with Severe Coxarthrosis. Medical Immunology. 2009;2(3):161-168.

2. Popkov VM, et al. Cytokines: Their Biologic Role in The Development of Adjustment and Damage Response Under Normal and Pathological Conditions of Various Genesis. Saratov: Saratov State Medical University n.a. V.I. Razumovsky; 2016. 448 p. 